\title{
"The impact of wise capital on the balanced performance of small enterprises in Iraq"
}

ARTICLE INFO

RELEASED ON

RECEIVED ON

ACCEPTED ON

LICENSE
AUTHORS

Amel Mahmood Ali AL-Obaidi (D https://orcid.org/0000-0002-0842-9739

Amel Mahmood Ali AL-Obaidi (2021). The impact of wise capital on the balanced performance of small enterprises in Iraq. Problems and Perspectives in Management, 19(1), 257-271. doi:10.21511/ppm.19(1).2021.22

http://dx.doi.org/10.21511/ppm.19(1).2021.22

Tuesday, 09 March 2021

Thursday, 14 May 2020

Monday, 11 January 2021

\section{(c) EY}

This work is licensed under a Creative Commons Attribution 4.0 International License

JOURNAL

"Problems and Perspectives in Management"

ISSN PRINT

$1727-7051$

ISSN ONLINE

$1810-5467$

PUBLISHER

LLC "Consulting Publishing Company "Business Perspectives"

FOUNDER

LLC "Consulting Publishing Company "Business Perspectives"
NUMBER OF REFERENCES

36

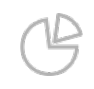

NUMBER OF FIGURES

4

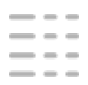

NUMBER OF TABLES

6

(C) The author(s) 2021. This publication is an open access article. 


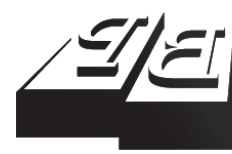

\section{BUSINESS PERSPECTIVES}

LLC "CPC "Business Perspectives" Hryhorii Skovoroda lane, 10, Sumy, 40022, Ukraine www.businessperspectives.org
Received on: $14^{\text {th }}$ of May, 2020 Accepted on: $11^{\text {th }}$ of January, 2021 Published on: $9^{\text {th }}$ of March, 2021

(C) Amel Mahmood Ali AL-Obaidi, 2021

Amel Mahmood Ali AL-Obaidi, Assistant Professor, Department of Finance, Faculty of Administration and Economics, Al-Mustansiriya University, Iraq.
This is an Open Access article, distributed under the terms of the Creative Commons Attribution 4.0 International license, which permits unrestricted re-use, distribution, and reproduction in any medium, provided the original work is properly cited.

Conflict of interest statement: Author(s) reported no conflict of interest
Amel Mahmood Ali AL-Obaidi (Iraq)

\section{THE IMPACT OF WISE CAPITAL ON THE BALANCED PERFORMANCE OF SMALL ENTERPRISES IN IRAQ}

\begin{abstract}
This study aims to examine the impact of wise capital on the performance of small enterprises in Iraq. Inference, innovation, social responsibility and independence are considered as wise capital dimensions. On the other hand, the financial dimension, customer dimension, learning and growth, and the operational dimension are treated as measures of enterprise performance. The study uses a sample of 207 respondents. Factor analysis and structural equation modeling were used to estimate the results. The results of the study indicate that two dimensions of wise capital, innovation and independence, have significant negative impacts on different measures of enterprise performance, but there is no evidence that inference and social responsibility affect the performance of enterprises in Iraq. This study has several contributions and implications. It contributes to the literature on wise capital and performance of small enterprises. It provides an opportunity for policy makers, regulators, academicians, and entrepreneurs to gain insight into the policy measures and remedies needed to improve the performance of small enterprises in Iraq.
\end{abstract}

\section{Keywords}

inference, innovation, social responsibility, independence, financial performance, small enterprises

\section{JEL Classification $\quad$ M10, O15, J24}

\section{INTRODUCTION}

Intellectual capital tends to be an important resource and a key contributor to the economic success and value creation in a business (Alabass, 2019). Firms perceive that all types of capital, such as physical and financial capital, are vital and strategic resources for their operations because these kinds of capital represent a competitive advantage and superior performance for business enterprises (Zeghal \& Maaloul, 2010). While prior studies (Al-Jubouri, 2019; Desoky \& Mousa, 2020; Almaqtari, Al-Hattami et al., 2020; Almaqtari, Frahan et al., 2020; Naushad, 2019; Shubita, 2019; Sidharta et al., 2019; Umanto et al., 2018; Al Maqtari et al., 2020) provided evidence of intellectual capital in different contexts, this study aims to investigate the impact of wise capital on the performance of small enterprises in Iraq. Small and medium-sized enterprises (SMEs) remained unexplored area of research in the context of wise capital and financial performance in Iraq. Accordingly, this study sheds light on the importance of wise capital dimensions for better performance of small enterprises in Iraq.

Due to the transformation of contemporary organizations from human resource organizations seeking to gain knowledge to those based on rare and wise human resources for the purpose of not wasting the opportunity to shift to small enterprise organizations, they should realize that wise capital is the source of thought and creativity and the basis for development and survival. To achieve competitive advantage 
and future success, small enterprises should possess managerial skills characterized by wise capital through the promotion of reasoning and insight, creativity and innovation, social responsibility, independence, and freedom. In line with the environmental progress, in particular, the technical progress, business organizations should pay attention to the quality of the human resource to achieve excellence and distinguished competence by emphasizing the importance of wise capital in enhancing performance and advancement. Therefore, this study identifies the problems small enterprises face to enhance the performance of these organizations. The significance of this study is due to the importance of its variables with a new synthesis, as this approach has not received enough attention from researchers, especially in small enterprises in Iraq, to enhance the capabilities of small business departments and increase their strengths. It also deals with modern ideas that are important for the success of contemporary enterprises in the contemporary environment. Accordingly, the aim of the study is to identify the contribution of wise capital to the performance of small enterprises.

This study has significant implications for policy makers, regulators, academicians, entrepreneurs and other parties in Iraq. It opens insights into the factors that affect the performance of small enterprises in Iraq. Regulators should give more consideration to the dimensions of wise capital, especially for enhancing the performance of small enterprises in Iraq, both inference and social responsibility. Policy makers and regulators should encourage small enterprises and give more liberal and motivating polices to enhance the performance of small enterprises.

\section{LITERATURE REVIEW}

\subsection{Wise capital}

\subsubsection{Inference}

It is a process of thinking that allows you to arrive at conclusions, generalizations, forecasts, and estimates for the purposes of analysis and creativity (Al-Azzawi, 2008, p. 5). It includes three skills, which are induction: that is, reaching a general rule of particles and special cases. The second is deduction: to reach a general rule and then apply it to particles and special cases, and finally, the conclusion: to reach a specific result from the introductions and available data. There is a set of criteria that a wise person must possess (Al-Kamari, 2012, p. 81) in the field of reasoning, which are clarity, accuracy, depth, logic, logical thinking, as well as having a far-sighted view of the consequences of things and a person's vision of future directions.

\subsubsection{Creativity and innovation}

Creativity is a pattern of thinking forward in accessing new and modern knowledge. Innovation is a new high-risk idea presented to the organization and implemented through a creative process. It can be in various types such as technological innovation through research efforts, or creativity of development processes for products, design, advertising, etc. (Dess \& Lumpkin, 2005, p. 150). AlHariri (2012, p. 155) defines it as the ability to collect or share information in ways that lead to new ideas or a creative solution to a problem or a new idea. (Carnall, 1999, p. 83) indicates that successful organizations drive foundations of independence to workers to encourage creativity and excellence. Creativity requires a set of important qualities in the creative personality. These characteristics are audacity and fluency, resilience, adventure and risk-taking, determination, curiosity, independence, and lush imagination (Mimar, 2004, p. 115). Creativity has many forms (Al-Qaryouti, 2005): the presentation of a new idea, gathering of unconnected ideas and their transformation into a new thing, expansion of an idea that has already been proposed, quotation, imitation and elicitation from the experiences of others to show a new form of a specific situation. Whereas innovation represents collecting and producing information in a unique manner and generating an idea that a new project benefit will from its implementation.

\subsubsection{Social responsibility}

It is an expression that refers to decisions and behaviors within the organization that depend on values and ideals. The recent trend of organizations towards global competition and innovation 
has led to increased social responsibility as they achieve returns and profits for the organization (Ferrell \& Hatline, 2005, p. 292). Today, the concept of social responsibility has become more extensive to include improving the quality of life, providing stability, and caring for all segments of society (Al-Maghrabi, 2006, p. 558). Social responsibility is defined as the performance of business in an economic, social and environmental manner provided that there is a kind of balance between the various stakeholders (Siwar \& Hossein, 2009, p. 290). Through its experience in the CSR missions of organizations, the UK has identified three main skills. Firstly, business skills that include business acumen, communication skills, decision making skills, business awareness, strategic awareness, leadership, and ability. Secondly, people's skills that are the ability to adapt and empathize, develop society, integrity, political awareness, and volunteerism. Thirdly, technical skills, which include technical expertise, understanding evaluation, stakeholder dialogue, and human rights. Therefore, it is an effective tool for public relations and social stability, raising awareness, social education and raising the level of individuals, contributing to technical development, eliminating unemployment, and finally, the commitment to social responsibility leads to maximizing state returns due to organizations' awareness of the importance of fair and correct contribution to bear social costs (Al-Zubaidi, 2012, p. 12).

\subsubsection{Independence}

It means the degree to which a person can freely take important decisions. Hence, the role of wise capital in the human resource represents the elite, which represents the activity and vitality of the organization. Collins (1996, p. 30) has emphasized that the problem of contemporary organizations is how to balance the need of management to control job performance and the desire to create internal commitment among people doing the job, since the degree to which self-control is permitted is part of the management philosophy and its administrative structure. Freedom of action and independence represents the extent of the individual's freedom to choose in setting standards of behavior in choosing ways to carry out his/her work tasks according to what he/she deems appropriate (Al-Malkawi 2015, p. 58).

\subsection{Performance of small enterprises}

Performance measurements for small projects are used to measure results that express goals set by departments. It should be noted that the performance of small enterprises is measured by several criteria, including the efficiency and effectiveness of achieving the goals, the satisfaction of workers, the renewal of their enthusiasm and loyalty to work and their feet to face challenges, and the exploitation of opportunities, the efficiency of crisis management, and moreover, the extent of their ability to absorb the human resource and the ability to creativity and innovation. Performance indicators include three aspects. The first is the indicators measuring the effectiveness, such as accuracy, quality, and customer response speed. The second is the indicators that measure the efficiency and the level of utilization of various available resources. The third aspect includes the indicators of resilience and adaptation to the environment (Elasrag, 2012, p. 30). The profitability of an enterprise can be measured by economic indicators, including the level of productivity, technology, and turnover.

Jamil and Mohamed (2011, p. 203) pointed to a set of systems used to measure performance, including the matrix performance system, the hierarchical performance system, the integrated performance measurement system, the results system and the determinants framework that measures the performance of service industries. The balanced performance card is the measure adopted in this study. It is a method for setting balanced goals for an enterprise and then measuring it so that it achieves strategic goals through a variety of goals, including financial, operational, customer satisfaction, superiority, and growth. It relates to defining measuring and developing the performance of individuals and teams and using their performance with strategic objectives of the enterprise.

Small enterprises can only flourish in a society with an entrepreneurial spirit and a passion for self-employment. Business owners and owners of administrative talents are guided, inferred, and have long-term insights to adopt various fields in small enterprises through the availability of the spirit of creativity, initiative and innovation (O'Donnell et al., 2006, p. 98). This can happen through the introduction of new methods of work 
and production, new products, improvements, innovations, or the transfer of a new idea that adopts a new business, and all this requires a lot of energy and capabilities that have the ability to reason, understand, create, innovate and striving for social responsibility with a space of freedom and independence to implement a long-term vision. The human resource is a key to operating and starting enterprises of all kinds due to its capabilities to determine the behavior of investors as it represents the lightness in the intellectual movement that can change practices and thinking to obtain innovative solutions to problems. It is the behavioral component of the work (Bontis \& Fitz-enz, 2002). This shows the level of performance and growth of enterprises.

They are organizations that are founded by individual or group initiatives to achieve returns and profits by providing a good or useful service to society. It includes three main elements (Afaneh \& Abu Obaid, 2010, p. 1): material resources of machinery, equipment and raw materials, human resources represented by personal skills at work, and finally, the source of profit, which is the primary goal of starting the project.

The International Labor Organization defines them as small industries, which are very small units that produce and distribute goods and services and consist of self-employed independent producers. They do not practice internationalization and depend on the experienced representatives represented by the CEO and relying on their own characteristics. Moreover, they are defined as projects that combine ownership, management, success and responsibility in the person of the owner. Management often depends on the intuition, skills and training that the manager owns (Krol, 2007, p. 4). A small enterprise is defined as an organization owned and managed by one individual or a limited number of individuals. They do not control the sector in which they operate (AlGhalbi, 2009, p. 24). They should be within the community's need, within the legitimacy of the activity, and have clear visions. They are considered an engine of growth, a basis for competition in the market, they reduce unemployment and poverty, and work for economic and social cohesion. They can reduce costs, reflect the correct use of knowledge and innovation, and promote learn- ing and training. They are considered platforms for new ideas (Al-Azzawi, 2008, p. 55).

These projects are distinguished in the Iraqi environment with some advantages resulting from the nature of their flexibility in both management and production. The most important characteristics of these enterprises are:

1) limited technological requirements;

2) limited ability to employ;

3) little capital as they depend on personal and family capital;

4) limited production capacity; and

5) environmental constraints in the use of expertise and skills.

The International Economic Development Organization indicated in a report prepared by the United States Agency for International Development that small projects get facilities from the chambers of commerce in the province councils as part of their development programs and provide facilities in obtaining the means of production and banking facilities. From the principle of community service, the Iraqi Council of Representatives has recommended the passage of a law for small and micro projects that includes the establishment of an Iraqi body to take care of these projects, just as the developed countries have in establishing new projects that attract young scientific and administrative staff to reduce unemployment and raise gross national product. The Iraqi company, which was established with financial support from the United States Agency for International Development, is supporting business incubators. It started its work in 2009. It is working on financing these projects and promoting the culture of lending to private banks in Iraq (Tarnoff, 2015, p. 15).

Table 1 is extracted from data from the Directorate of Industrial Statistics, Central Statistics Authority in Iraq. The period from 2000-2003 represents the beginning of horizontal expansion in that industry. Enterprises reached 77,167 in 2000, which is the highest number in previous years. They began to decline in 2001 to 69,090 . The decline continued until 2003 when it reached 17,929 due to political and economic reasons at the time. The decline continued until 2009 due to the difficult economic 
Table 1. Summary of industrial statistics results for small enterprises for 2015-2018

\begin{tabular}{|c|c|c|c|c|c|}
\hline Indicators/years & 2015 & 2016 & 2017 & 8102 & $\begin{array}{c}\text { Variance percentage } \\
\text { between the two years } \\
\text { (2017-2018) }\end{array}$ \\
\hline Number of establishments & 22,480 & 25,966 & 27,856 & 747,52 & -7.6 \\
\hline Total number of employees & 67,157 & 81,920 & 93,644 & 573,38 & -11.0 \\
\hline The number of paid workers & 42,616 & 53,022 & 58,954 & 716,45 & -7.4 \\
\hline Total wages and benefits (million dinars) & 261,492 & 333,111 & 304,412 & 108,892 & -1.8 \\
\hline Total production value (million dinars) & 182,396 & 207,991 & $2,016,330$ & $982,939,1$ & -3.8 \\
\hline $\begin{array}{l}\text { Value of production inputs (million } \\
\text { dinars) }\end{array}$ & 978,754 & 102,651 & $1,008,495$ & $972,720,1$ & 1.9 \\
\hline
\end{tabular}

situation that impeded the development of projects and human resources, as well as strong competition between the products of these projects and imported products whose low prices. This led to the suspension of many projects as shown by the published statistics from the Central Bureau of Statistics.

The years 2015-2017 saw an increase in the number of projects, as well as an increase in the total number of workers. As for the year 2018, it is noticed that there is a decrease in the number of projects by $7.6 \%$ due to a comprehensive modernization of the framework of small industrial enterprises for that year. Since 2013, the framework has not been updated due to the financial distress that the country was going through and the decrease in the percentage of workers, as well as the value of wages and benefits and the value of production, as shown in Table 1 (Central Statistical Organization, 2019, pp. 6-7).

This requires a study of every variable or factor that can play a role in developing and increasing these enterprises: human resources, intellectual and wise capital, as they are real capital and the main driver of these enterprises, their role and impact in advancing these enterprises, which, in turn, contributes to raising the standard of living, reducing unemployment, enhancing the role of social responsibility towards the country, and encouraging creativity and innovation through human response.

\section{AIM OF THE STUDY}

The main aim of this study is to examine the contribution of wise capital to the performance of small enterprises in Iraq. Wise capital is measured by four dimensions, namely, inference and insight, creativity and innovation, social responsibility, and independence and freedom. Accordingly, the sub-objectives of the study are as follows:

a) To study the impact of wise capital dimensions on the financial dimension of small enterprises in Iraq.

b) To study the impact of wise capital dimensions on the customer dimension of small enterprises in Iraq.

c) To study the impact of wise capital dimensions on the operational dimension of small enterprises in Iraq.

d) To study the impact of wise capital dimensions on the learning and growth dimension of small enterprises in Iraq.

\section{HYPOTHESES OF THE STUDY}

This study attempts to investigate the impact of wise capital on the performance of small enterprises in Iraq. The following are the hypotheses of the study:

$H_{0} 1$ : There is no significant impact of wise capital dimensions, namely, inference and insight, creativity and innovation, social responsibility, and independence and freedom, on the financial dimension of small enterprises in Iraq.

$\mathrm{H}_{0}$ 2: There is no significant impact of wise capital dimensions, namely inference and insight, creativity and innovation, social responsibility, and independence and freedom, on the customer dimension of small enterprises in Iraq. 
$H_{0}$ 3: There is no significant impact of wise capital dimensions, namely, inference and insight, creativity and innovation, social responsibility, and independence and freedom, on the operational dimension of small enterprises in Iraq.

$H_{0} 4:$ There is no significant impact of wise capital dimensions, namely, inference and insight, creativity and innovation, social responsibility, and independence and freedom, on the learning and growth dimension of small enterprises in Iraq.

\section{RESEARCH METHODOLOGY}

Figure 1 demonstrates the research framework. The dimensions of wise capital (inference and insight, creativity and innovation, social responsibility, independence and freedom) have been regressed against the performance of small enterprises measured by the financial dimension, customer dimension, operational dimension, and learning and growth dimension. A 5-point Likert scale ranging from 1 (strongly disagree) to 5 (strongly agree) was used to measure each variable. A questionnaire survey has been used to collect the data required for this study.

The study examines the impact of wise capital on the performance of small enterprises in Iraq. Accordingly, the population of the study consists of 207 respondents. A sample of the small business community in Iraq was tested with information from CSO; Directorate of Industrial Statistics for small enterprises in Iraq. Convenience sampling method was used to collect data for this study. This method is commonly used by previous research as the population of the study is large and difficult to cover. Table 2 illustrates the sample size and sampling adequacy. The sampling adequacy has been tested using the Kaiser-Meyer-Olkin (KMO) measure. The value of $\mathrm{KMO}$ and Bartlett's Test is 0.944 (>0.50), which is higher than the criterion value (0.50). This signifies that the variance proportion of the study variables are suitable with the data used by this study. Further, Chi-Square value is $18,707.479$ with a degree of freedom of 496 and a probability value of $1 \%$ significance $(\mathrm{p}=0.000<0.01)$, which all signify the appropriateness of the sampling adequacy.

Table 2. Sample and sampling adequacy

\begin{tabular}{|c|c|}
\hline Particulars & No. \\
\hline Total no. of questionnaires distributed & 236 \\
\hline$(-)$ Uncollected & 27 \\
\hline (-) Forms with missing data & 2 \\
\hline Final sample & 207 \\
\hline \multicolumn{2}{|l|}{ KMO and Bartlett's Test } \\
\hline Kaiser-Meyer-Olkin measure of sampling adequacy & 0.944 \\
\hline \multicolumn{2}{|l|}{ Bartlett's Test of sphericity } \\
\hline Approx. Chi-square & 18707.479 \\
\hline Df & 496 \\
\hline Sig. & 0.000 \\
\hline
\end{tabular}

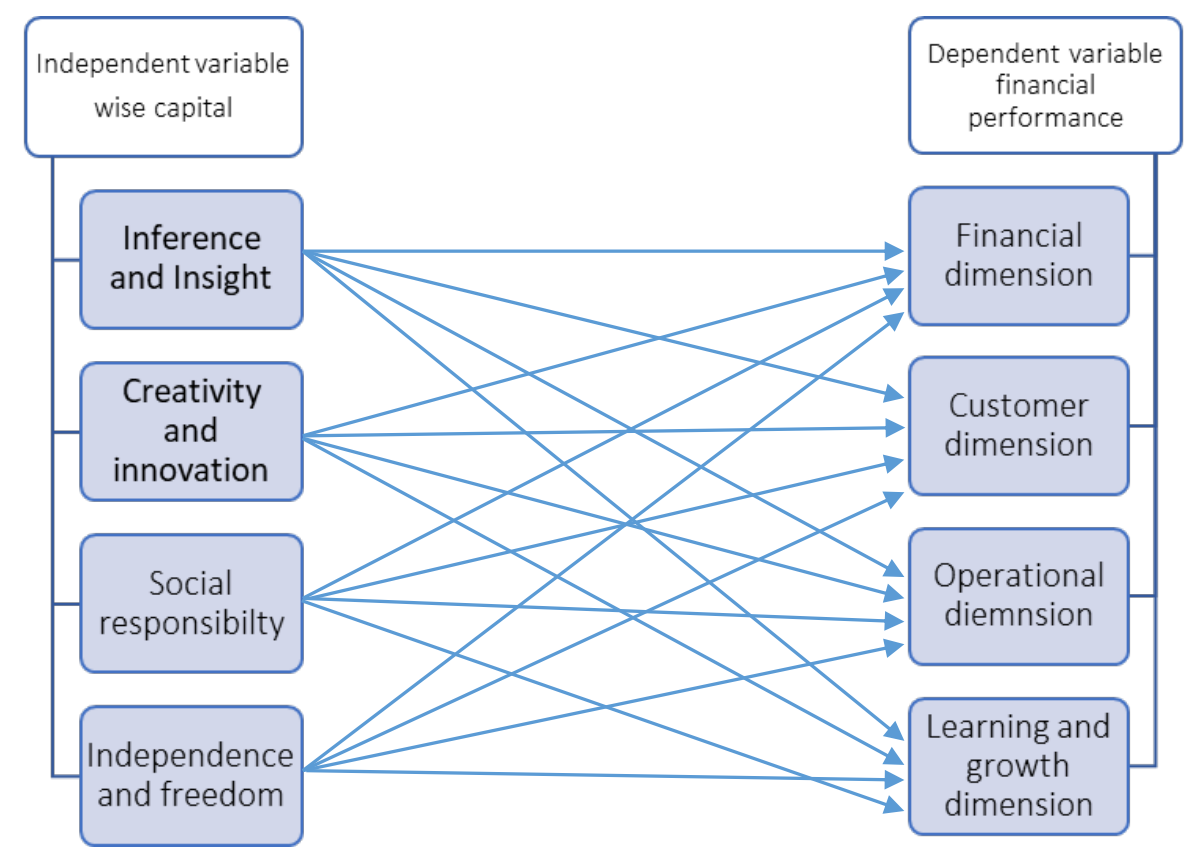

Figure 1. Research model 


\section{RESULTS}

\subsection{Model measurement}

Figure 2 demonstrates confirmatory factor analysis for the items used by the study through the research instrument applied.

Table 3 presents the outcomes of the measurement model that include descriptive statistics, factor loadings, Cronbach Alpha, Composite Reliability (CR), and Average Variance Extracted (AVE). The results show that the majority of items have an average value about 4 , which indicates the scale of "Agree". It means that the majority of respondents agree with statements of these items. Further, the values of skewness for all items are in the range of \pm 1 , and the values of the kurtosis are in the range of \pm 3 , which indicates a normal distribution of the data. Concerning factor analysis and dimension reduction, the results show that factor loadings have values that vary between a maximum value of 0.989 and a minimum value of 0.923 . These values are greater than the accepted value, which is 0.40 that has been suggested by prior research.
In the same context, the reliability values have a minimum value of 0.0 .976 and a maximum value of 0.987 , which indicates the fitness of the latent construct and the degree to which the items in the construct reflect the latent construct. Composite reliability values have a minimum value of 0.983 and a maximum value of 0.990 , which indicates the degree to which the items in the construct reflecting the latent construct are fit. Moreover, the extracted values of the average variance, which signify the overall amount of variance in the indicators accounted for by the latent construct, have values in the range from the minimum 0.934 to the maximum 0.964 , which exceeds the criterion value, 0.50 (Figure 3).

Discriminant validity indicates that the values exhibit the extent to which the measures are not a reflection of some other variables. Table 4 shows that each variable is significantly correlated with its related variable. This indicates that each variable is highly related to its construct. All the items represent their constructs and variables, not any other variables. This is also confirmed by the results in Table 5 that

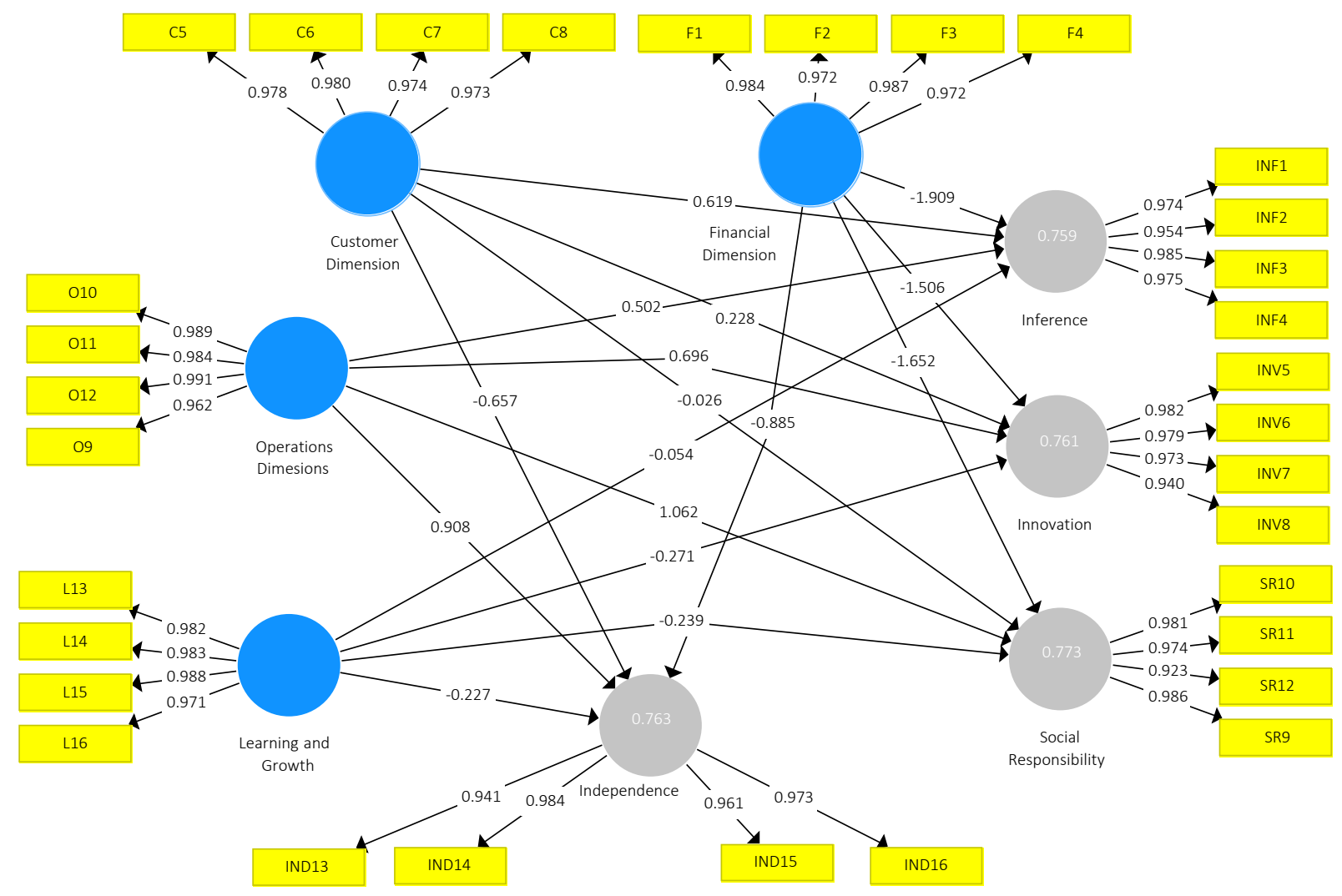

Figure 2. Confirmatory factor analysis 
Table 3. Validity and reliability for constructs

\begin{tabular}{|c|c|c|c|c|c|c|c|c|c|c|c|c|}
\hline \multirow{2}{*}{ Variables } & \multirow{2}{*}{ Items } & \multirow{2}{*}{$\begin{array}{c}\text { Mean } \\
\text { Statistic }\end{array}$} & \multirow{2}{*}{$\begin{array}{c}\text { Std. deviation } \\
\text { Statistic }\end{array}$} & \multicolumn{2}{|c|}{ Skewness } & \multicolumn{2}{|c|}{ Kurtosis } & \multirow{2}{*}{$\begin{array}{c}\text { Factor } \\
\text { loading }\end{array}$} & \multirow{2}{*}{ CA } & \multirow{2}{*}{ rho_A } & \multirow{2}{*}{ CR } & \multirow{2}{*}{ AVE } \\
\hline & & & & Statistic & Std. error & Statistic & Std. error & & & & & \\
\hline \multirow{4}{*}{ Financial dimension } & F1 & 3.406 & 1.1985 & -.467 & .169 & -.665 & .337 & 0.984 & \multirow{4}{*}{0.984} & \multirow{4}{*}{0.985} & \multirow{4}{*}{0.988} & \multirow{4}{*}{0.953} \\
\hline & $F 2$ & 3.507 & 1.2143 & -.510 & .169 & -.892 & .337 & 0.972 & & & & \\
\hline & F3 & 3.319 & 1.2247 & -.342 & .169 & -.931 & .337 & 0.987 & & & & \\
\hline & $\mathrm{F} 4$ & 3.174 & 1.2536 & -.289 & .169 & -.803 & .337 & 0.972 & & & & \\
\hline \multirow{4}{*}{ Customer dimension } & C5 & 3.667 & 1.1659 & -.604 & .169 & -.422 & .337 & 0.978 & \multirow{4}{*}{0.985} & \multirow{4}{*}{0.986} & \multirow{4}{*}{0.989} & \multirow{4}{*}{0.958} \\
\hline & C6 & 3.406 & 1.3144 & -.434 & .169 & -.936 & .337 & 0.980 & & & & \\
\hline & C7 & 3.797 & 1.2017 & -.772 & .169 & -.344 & .337 & 0.974 & & & & \\
\hline & $\mathrm{C} 8$ & 3.217 & 1.2642 & -.286 & .169 & -.885 & .337 & 0.973 & & & & \\
\hline \multirow{4}{*}{$\begin{array}{l}\text { Operational } \\
\text { dimension }\end{array}$} & 09 & 3.710 & 1.2200 & -.692 & .169 & -.574 & .337 & 0.989 & \multirow{4}{*}{0.975} & \multirow{4}{*}{0.978} & \multirow{4}{*}{0.982} & \multirow{4}{*}{0.931} \\
\hline & 010 & 3.420 & 1.2472 & -.612 & .169 & -.618 & .337 & 0.984 & & & & \\
\hline & 011 & 3.362 & 1.1571 & -.515 & .169 & -.552 & .337 & 0.991 & & & & \\
\hline & 012 & 3.406 & 1.2226 & -.528 & .169 & -.647 & .337 & 0.962 & & & & \\
\hline & L13 & 3.333 & 1.1278 & -.317 & .169 & -.772 & .337 & 0.982 & & & & \\
\hline Learning/Growth & L14 & 3.406 & 1.2462 & -.490 & .169 & -.760 & .337 & 0.983 & & & & \\
\hline dimension & L15 & 3.304 & 1.1984 & -.401 & .169 & -.697 & .337 & 0.988 & 0.981 & 0.982 & 0.986 & 0.945 \\
\hline & L16 & 3.362 & 1.4173 & -.290 & .169 & -1.266 & .337 & 0.971 & & & & \\
\hline & INF1 & 4.10 & .983 & -1.322 & .169 & 1.613 & .337 & 0.974 & & & & \\
\hline & INF2 & 3.90 & .809 & -1.163 & .170 & 2.116 & .339 & 0.954 & & & & \\
\hline Interence and Insight & INF3 & 4.00 & .950 & -1.234 & .169 & 1.627 & .337 & 0.985 & $0.9 / 8$ & $0.9 / 9$ & 0.984 & 0.939 \\
\hline & INF4 & 3.96 & 1.030 & -1.042 & .169 & .613 & .337 & 0.975 & & & & \\
\hline & INV5 & 3.84 & 1.178 & -.983 & .169 & .048 & .337 & 0.982 & & & & \\
\hline Creativity and & INV6 & 3.99 & 1.031 & -1.018 & .169 & .572 & .337 & 0.979 & & & & \\
\hline innovation & INV7 & 3.94 & 1.078 & -1.082 & .169 & .656 & .337 & 0.973 & 0.987 & 0.987 & 0.99 & 0.963 \\
\hline & INV8 & 3.81 & 1.123 & -.807 & .169 & -.100 & .337 & 0.940 & & & & \\
\hline & SR9 & 3.77 & 1.172 & -.965 & .169 & .148 & .337 & 0.981 & & & & \\
\hline Social responsibility & SR10 & 3.81 & 1.186 & -1.111 & .169 & .470 & .337 & 0.974 & & & & \\
\hline Social responsibility & SR11 & 3.83 & 1.182 & -.994 & .169 & .206 & .337 & 0.923 & 0.981 & 0.988 & 0.991 & 0.964 \\
\hline & SR12 & 3.42 & 1.259 & -.570 & .169 & -.671 & .337 & 0.986 & & & & \\
\hline & IND13 & 3.78 & 1.036 & -.505 & .169 & -.252 & .337 & 0.941 & & & & \\
\hline Independence and & IND14 & 3.58 & 1.044 & -.796 & .169 & .266 & .337 & 0.984 & & & & \\
\hline freedom & IND15 & 3.42 & 1.200 & -.602 & .169 & -.503 & .337 & 0.961 & 0.976 & 0.977 & 0.983 & 0.934 \\
\hline & IND16 & 3.64 & 1.079 & -.782 & .169 & .142 & .337 & 0.973 & & & & \\
\hline
\end{tabular}

Note: CA is Cronbach's Alpha, CR is Composite Reliability, and AVE is Average Variance Extracted. 

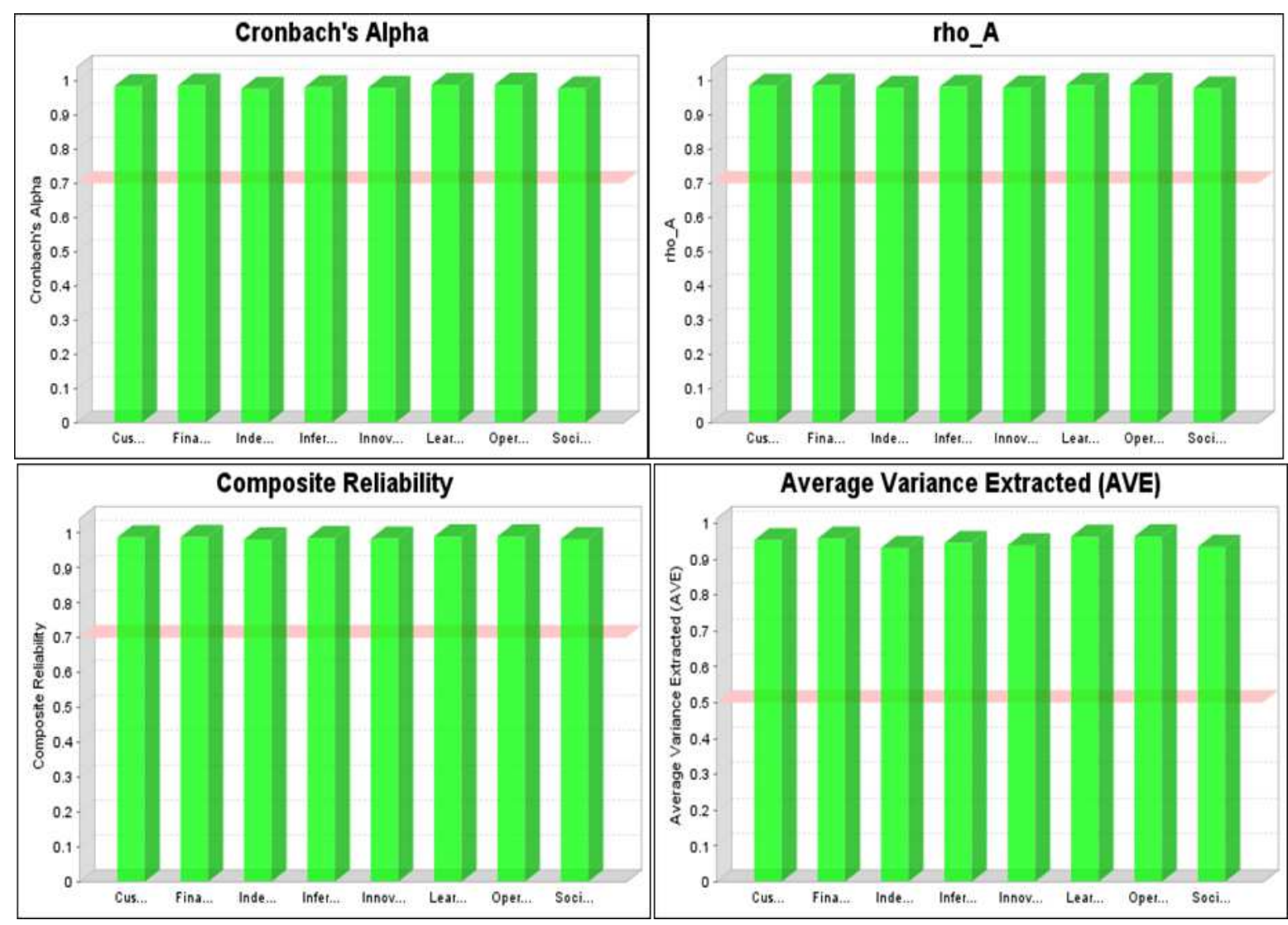

Figure 3. Cronbach Alpha, Roh_A, Average Variance Extracted, and Composite Reliability

Table 4. Discriminant validity

\begin{tabular}{|c|c|c|c|c|c|c|c|c|}
\hline Variables & $\begin{array}{l}\text { Customer } \\
\text { dimension }\end{array}$ & $\begin{array}{c}\text { Financial } \\
\text { dimension }\end{array}$ & Independence & Inference & Innovation_ & $\begin{array}{l}\text { Learning } \\
\text { and } \\
\text { growth }\end{array}$ & $\begin{array}{l}\text { Operational } \\
\text { dimension }\end{array}$ & $\begin{array}{c}\text { Social } \\
\text { responsibility }\end{array}$ \\
\hline $\begin{array}{l}\text { Customer } \\
\text { dimension }\end{array}$ & 0.984 & - & - & - & - & - & - & - \\
\hline $\begin{array}{l}\text { Financial } \\
\text { dimension }\end{array}$ & 0.976 & 0.988 & - & - & - & - & - & - \\
\hline Independence & -0.86 & -0.86 & 0.965 & - & - & - & - & - \\
\hline Inference & -0.819 & -0.857 & 0.912 & 0.972 & - & - & - & - \\
\hline Innovation_ & -0.838 & -0.864 & 0.912 & 0.970 & 0.979 & - & - & - \\
\hline $\begin{array}{l}\text { Learning and } \\
\text { growth }\end{array}$ & 0.983 & 0.99 & -0.856 & -0.841 & -0.854 & 0.985 & - & - \\
\hline $\begin{array}{l}\text { Operational } \\
\text { dimension }\end{array}$ & 0.982 & 0.979 & -0.835 & -0.829 & -0.835 & 0.951 & 0.982 & - \\
\hline $\begin{array}{l}\text { Social } \\
\text { responsibility }\end{array}$ & -0.843 & -0.865 & 0.941 & 0.953 & 0.961 & -0.854 & -0.83 & 0.967 \\
\hline
\end{tabular}

demonstrate the items' effect wise on the respective construct. The results show that the items of each variable have a statistically significant effect at the level of $1 \%$ (P-Value $=0.000<$ $0.01)$ on the respective variable, which indicates that the items are related and representing their variables.

\subsection{Structural model}

Structural Equation Modeling (SEM) is used to estimate the results. SEM is used to examine the effect of wise capital on the performance of small enterprises. Figure 4 provides the hypothesized structural model of this study. 
Table 5. Item wise effect on variables

\begin{tabular}{|c|c|c|c|c|}
\hline Items and variables & Original sample (0) & Standard deviation (STDEV) & T Statistics (|O/STDEV $\mid)$ & $P$ values \\
\hline \multicolumn{5}{|c|}{ Dependent variables } \\
\hline \multicolumn{5}{|c|}{ Financial dimension } \\
\hline $\mathrm{F} 1 \leftarrow$ Financial dimension & 0.984 & 0.002 & 396.342 & 0.000 \\
\hline $\mathrm{F} 2 \leftarrow$ Financial dimension & 0.971 & 0.004 & 261.839 & 0.000 \\
\hline $\mathrm{F} 3 \leftarrow$ Financial dimension & 0.987 & 0.002 & 465.822 & 0.000 \\
\hline F4 $\leftarrow$ Financial dimension & 0.972 & 0.004 & 271.213 & 0.000 \\
\hline \multicolumn{5}{|c|}{ Customer dimension } \\
\hline C5 $\leftarrow$ Customer dimension & 0.978 & 0.002 & 428.808 & 0.000 \\
\hline $\mathrm{C} 6 \leftarrow$ Customer dimension & 0.980 & 0.002 & 507.216 & 0.000 \\
\hline $\mathrm{C} 7 \leftarrow$ Customer dimension & 0.974 & 0.003 & 365.393 & 0.000 \\
\hline $\mathrm{C} 8 \leftarrow$ Customer dimension & 0.973 & 0.002 & 401.635 & 0.000 \\
\hline \multicolumn{5}{|c|}{ Operations dimension } \\
\hline $010 \leftarrow$ Operational dimensions & 0.989 & 0.002 & 557.423 & 0.000 \\
\hline O11 $\leftarrow$ Operational dimensions & 0.984 & 0.003 & 387.012 & 0.000 \\
\hline $012 \leftarrow$ Operational dimensions & 0.991 & 0.001 & 886.923 & 0.000 \\
\hline $09<$ Operational dimensions & 0.963 & 0.004 & 248.205 & 0.000 \\
\hline \multicolumn{5}{|c|}{ Learning and growth dimension } \\
\hline L13 $\leftarrow$ Learning and growth & 0.982 & 0.002 & 421.732 & 0.000 \\
\hline L14 $\leftarrow$ Learning and growth & 0.983 & 0.003 & 350.548 & 0.000 \\
\hline L15 $\leftarrow$ Learning and growth & 0.988 & 0.002 & 529.056 & 0.000 \\
\hline L16 $\leftarrow$ Learning and growth & 0.971 & 0.003 & 291.442 & 0.000 \\
\hline \multicolumn{5}{|c|}{ Independent variables } \\
\hline \multicolumn{5}{|c|}{ Inference dimension } \\
\hline INF1 $\leftarrow$ Inference & 0.974 & 0.005 & 180.911 & 0.000 \\
\hline INF2 $\leftarrow$ Inference & 0.955 & 0.008 & 122.983 & 0.000 \\
\hline INF3 $\leftarrow$ Inference & 0.985 & 0.003 & 314.421 & 0.000 \\
\hline INF4 $<$ Inference & 0.975 & 0.004 & 218.584 & 0.000 \\
\hline \multicolumn{5}{|c|}{ Innovation dimension } \\
\hline INV5 $\leftarrow$ Innovation & 0.982 & 0.002 & 395.320 & 0.000 \\
\hline INV $6 \leftarrow$ Innovation & 0.979 & 0.003 & 284.730 & 0.000 \\
\hline INV7 $\leftarrow$ Innovation & 0.973 & 0.007 & 141.132 & 0.000 \\
\hline INV8 $\leftarrow$ Innovation_ & 0.941 & 0.010 & 96.466 & 0.000 \\
\hline \multicolumn{5}{|c|}{ Social Responsibility dimension } \\
\hline SR10 $\leftarrow$ Social responsibility & 0.981 & 0.003 & 308.602 & 0.000 \\
\hline SR11 $\leftarrow$ Social responsibility & 0.974 & 0.005 & 192.689 & 0.000 \\
\hline SR12 $\leftarrow$ Social responsibility & 0.924 & 0.011 & 87.061 & 0.000 \\
\hline SR9 $\leftarrow$ Social responsibility & 0.986 & 0.002 & 442.584 & 0.000 \\
\hline \multicolumn{5}{|c|}{ Independence dimension } \\
\hline IND13 $\leftarrow$ Independence & 0.940 & 0.008 & 114.416 & 0.000 \\
\hline IND14 $\leftarrow$ Independence & 0.985 & 0.002 & 488.347 & 0.000 \\
\hline IND15 \& Independence & 0.961 & 0.005 & 182.504 & 0.000 \\
\hline IND16 $<$ Independence & 0.974 & 0.004 & 227.921 & 0.000 \\
\hline
\end{tabular}

The results in Table 6 provide a path analysis and hypotheses testing using SEM. The results demonstrate four models that test the impact of wise capital dimensions (inference, innovation, social responsibility and independence) on performance measures (financial dimension, customer dimension, operations dimension and learning and growth). The results in model 1 show that both innovation and independence have a statistically significant effect on the enterprise performance as measured by the financial dimension. Innovation exhibits a statistically significant negative effect on enterprise performance as measured by the financial dimension at the level of $5 \%(\mathrm{p}=0.014<0.05)$. Hence, $H_{0} 1$ is rejected in the context of innovation and independence. Similarly, independence has a statistically significant negative effect on the enterprises' performance as measured by the financial dimension at the level of $1 \%(\mathrm{p}=0.000<0.01)$. However, there is no significant effect of inference 


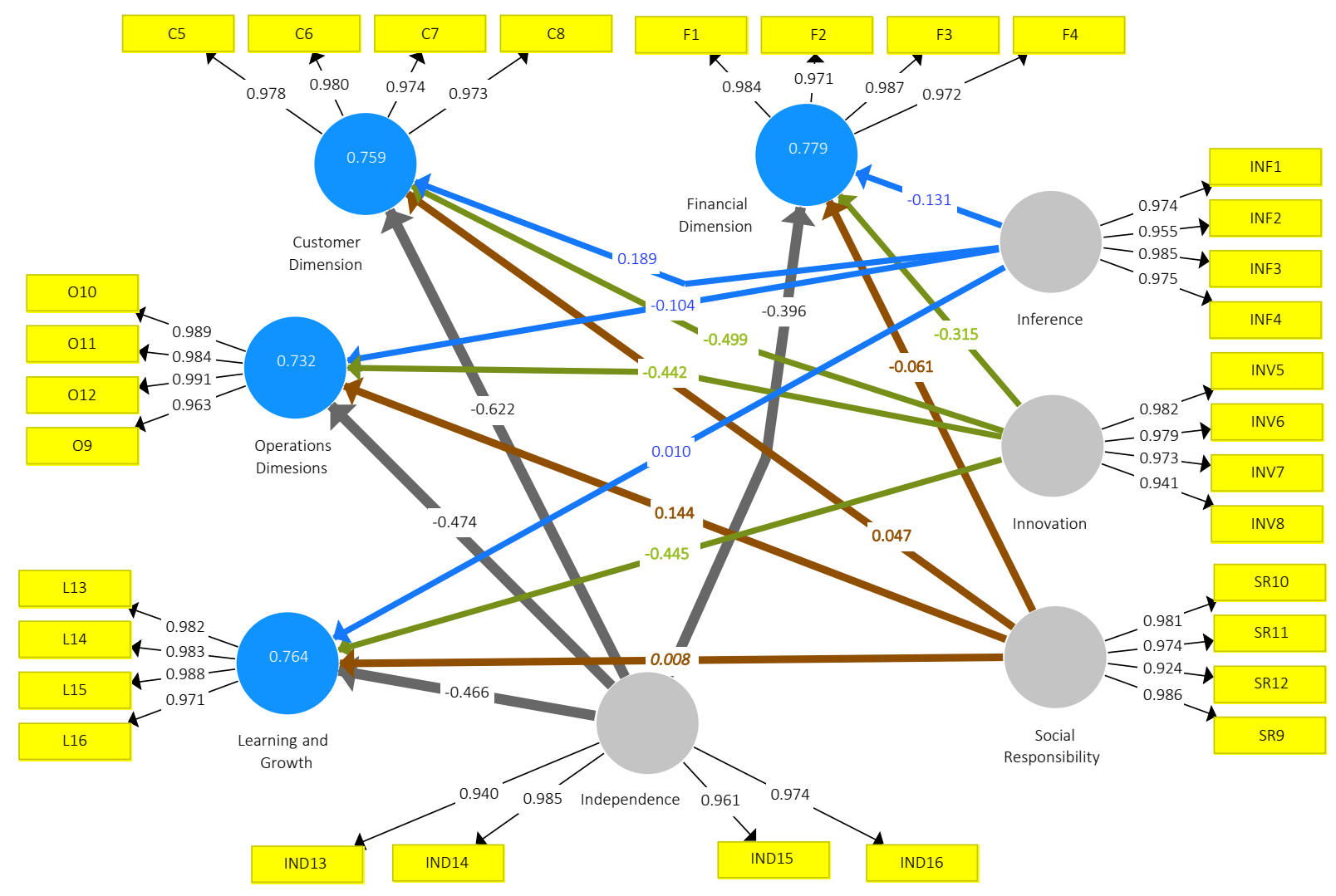

Figure 4. Structural equation modeling

and social responsibility on the enterprises' performance as measured by the financial dimension at any level of significance, $10 \%, 5 \%$, and $1 \%$ ( $\mathrm{P}$-value $>0.10$ ). Hence, $H_{0} 1$ is accepted in the context of inference and social responsibility. Overall, the value of adjusted R-squared indicates that the variables explain about $77 \%$ of enterprise performance as measured by the financial dimension.

Concerning the impact of wise capital dimensions of performance as measured by the customer dimension, the results in model 2 show that both innovation and independence have a statistically significant effect on the enterprises' performance as measured by the customer dimension. Both innovation and independence exhibit a statistically significant negative effect on the enterprise's performance as measured by the customer dimension at the level of $1 \%(\mathrm{p}=0.000<0.01)$. Accordingly, $\mathrm{H}_{0} 2$ is rejected in the context of innovation and independence. However, there is no significant effect of inference and social responsibility on the enterprises' performance as measured by the customer dimension at any level of significance, $10 \%, 5 \%$, and $1 \%$ (P-value $>0.10$ ). Hence, $H_{0} 2$ is accepted in the context of inference and social responsibility. Collectively, the value of adjusted R-squared signifies that the wise capital variables contribute about $75 \%$ of the variation to enterprise performance as measures by the financial dimension.

The impact of wise capital dimensions of performance as measured by the operational dimension is presented in model 3. The results show that both innovation and independence have a statistically significant negative effect on the enterprises' performance as measured by the operational dimension at the level of $1 \%(\mathrm{p}=0.000<$ 0.01 ). Accordingly, $H_{0} 3$ is rejected in the context of innovation and independence. However, there is no significant effect of inference and social responsibility on the enterprises' performance as measured by the operational dimension at any level of significance, $10 \%, 5 \%$, and $1 \%$ (P-value $>0.10$ ). Hence, $H_{0} 3$ is accepted in the context of inference and social responsibility. Overall, the value of adjusted $\mathrm{R}$-squared indicates that wise capital variables contribute about $73 \%$ to the enterprises' performance as measured by the financial dimension. 
Table 6. Structural model

\begin{tabular}{|c|c|c|c|c|c|}
\hline Path & Std. beta & SD. & T statistics & P value & Result \\
\hline \multicolumn{6}{|c|}{ Model (1) The impact of Wise Capital dimensions of performance as measured by the financial dimension } \\
\hline Inference $\rightarrow$ Financial dimension & -0.131 & 0.149 & 0.881 & 0.379 & Supported \\
\hline Innovation $\rightarrow$ Financial dimension & -0.315 & 0.127 & 2.473 & 0.014 & Not supported \\
\hline Social responsibility $\rightarrow$ Financial dimension & -0.061 & 0.156 & 0.392 & 0.695 & Supported \\
\hline Independence $\rightarrow$ Financial dimension & -0.396 & 0.088 & 4.529 & 0.000 & Not supported \\
\hline R-Squared & \multicolumn{3}{|c|}{-} & 0.779 & - \\
\hline Adjusted R-Squared & \multicolumn{3}{|c|}{-} & 0.774 & - \\
\hline \multicolumn{6}{|c|}{ Model (2) The impact of Wise Capital dimensions of performance as measured by the customer dimension } \\
\hline Inference $\rightarrow$ Customer dimension & 0.189 & 0.168 & 1.127 & 0.260 & Supported \\
\hline Innovation_ $\rightarrow$ Customer dimension & -0.499 & 0.134 & 3.717 & 0.000 & Not supported \\
\hline Social responsibility $\rightarrow$ Customer dimension & 0.047 & 0.143 & 0.325 & 0.746 & Supported \\
\hline Independence $\rightarrow$ Customer dimension & -0.622 & 0.079 & 7.820 & 0.000 & Not supported \\
\hline R-Squared & \multicolumn{3}{|c|}{-} & 0.759 & - \\
\hline Adjusted R-Squared & \multicolumn{3}{|c|}{-} & 0.754 & - \\
\hline \multicolumn{6}{|c|}{ Model (3) The impact of Wise Capital dimensions of performance as measured by the financial dimension } \\
\hline Inference $\rightarrow$ Operations dimensions & -0.104 & 0.163 & 0.640 & 0.522 & Supported \\
\hline Innovation $\rightarrow$ Operations dimensions & -0.442 & 0.129 & 3.416 & 0.001 & Not supported \\
\hline Social responsibility $\rightarrow$ Operations dimensions & 0.144 & 0.151 & 0.953 & 0.341 & Supported \\
\hline Independence $\rightarrow$ Operations dimensions & -0.474 & 0.085 & 5.544 & 0.000 & Not supported \\
\hline R-Squared & \multicolumn{3}{|c|}{-} & 0.732 & - \\
\hline Adjusted R-Squared & \multicolumn{3}{|c|}{-} & 0.727 & - \\
\hline \multicolumn{6}{|c|}{ Model (4) The impact of Wise Capital dimensions of performance as measured by the financial dimension } \\
\hline Inference $\rightarrow$ Learning and growth & 0.010 & 0.156 & 0.063 & 0.950 & Supported \\
\hline Innovation $\rightarrow$ Learning and growth & -0.445 & 0.134 & 3.324 & 0.001 & Not supported \\
\hline Social responsibility $\rightarrow$ Learning and growth & 0.008 & 0.159 & 0.049 & 0.961 & Supported \\
\hline Independence $\rightarrow$ Learning and growth & -0.466 & 0.094 & 4.975 & 0.000 & Not supported \\
\hline R-Squared & \multicolumn{3}{|c|}{-} & 0.764 & - \\
\hline Adjusted R-Squared & \multicolumn{3}{|c|}{-} & 0.760 & - \\
\hline
\end{tabular}

Model 4 in Table 6 shows the impact of wise capital dimensions of performance as measured by the learning and growth dimension. The results show that both innovation and independence have a statistically significant negative effect on the enterprises' performance as measured by the learning and growth dimension at the level of $1 \%$ $(\mathrm{p}=0.000<0.01)$. Accordingly, $H_{0} 4$ is rejected in the context of innovation and independence. However, there is no significant effect of infer- ence and social responsibility on the enterprises' performance as measured by the learning and growth dimension at any level of significance, $10 \%, 5 \%$, and $1 \%$ (P-value $>0.10$ ). Hence, $H_{0} 4$ is accepted in the context of inference and social responsibility. In general, the value of adjusted $\mathrm{R}$-squared is $76 \%$, which indicates that wise capital variables explain $76 \%$ of the variability of enterprise performance as measured by the financial dimension.

\section{CONCLUSION}

The study examines the impact of wise capital on the performance of small enterprises in Iraq. Wise capital dimensions (inference, innovation, social responsibility and independence) are statistically functioned against enterprises' performance measures (financial dimension, customer dimension, operations dimension and learning and growth). A 5-point Likert scale ranging from 1 (strongly disagree) to 5 (strongly agree) was used to measure the variables. A questionnaire survey includes four items for each variable used to collect data. The sample consisted of 207 respondents. Factor analysis and structural equation modeling were used to estimate the results. 
The results revealed that both innovation and independence have a statistically significant effect on the enterprises' performance as measured by the financial dimension. Innovation exhibited a statistically significant negative effect on the enterprises' performance as measured by the financial dimension. Similarly, independence has a statistically significant negative effect on the enterprises' performance as measured by the financial dimension. However, there was no significant effect of inference and social responsibility on the enterprises' performance as measured by the financial dimension. Concerning the impact of wise capital dimensions of performance as measured by the customer dimension, the results in the model indicated that both innovation and independence had a statistically significant effect on the enterprises' performance as measured by the customer dimension. Both innovation and independence exhibited a statistically significant negative effect on the enterprises' performance as measured by the customer dimension. However, there was no significant effect of inference and social responsibility on the enterprises' performance as measured by the customer dimension

The results also show that both innovation and independence have a statistically significant negative effect on the enterprises' performance as measured by the operational dimension. However, there was no significant effect of inference and social responsibility on the enterprises' performance as measured by the operational dimension. Finally, the results showed that both innovation and independence had a statistically significant negative effect on the enterprises' performance as measured by the learning and growth dimension. However, there is no significant effect of inference and social responsibility on the enterprises' performance as measured by the learning and growth dimension.

\section{AUTHOR CONTRIBUTIONS}

Conceptualization: Amel Mahmood Ali AL-Obaidi.

Data curation: Amel Mahmood Ali AL-Obaidi.

Formal analysis: Amel Mahmood Ali AL-Obaidi.

Funding acquisition: Amel Mahmood Ali AL-Obaidi.

Investigation: Amel Mahmood Ali AL-Obaidi.

Methodology: Amel Mahmood Ali AL-Obaidi.

Project administration: Amel Mahmood Ali AL-Obaidi.

Resources: Amel Mahmood Ali AL-Obaidi.

Software: Amel Mahmood Ali AL-Obaidi.

Supervision: Amel Mahmood Ali AL-Obaidi.

Validation: Amel Mahmood Ali AL-Obaidi.

Visualization: Amel Mahmood Ali AL-Obaidi.

Writing - original draft: Amel Mahmood Ali AL-Obaidi.

Writing - review \& editing: Amel Mahmood Ali AL-Obaidi.

\section{REFERENCES}

1. Afaneh, J., \& Abu Obeid, Q. (2010). 3. Alabass, H. S. H. H. (2019). Small Enterprise Management. Al- Intellectual capital and financial Yazouri Publishing House.

2. Al Maqtari, F. A., Farhan, N. H., Al-Hattami, H. M., \& Khalid, A. S. (2020). Impact of countrylevel corporate governance on entrepreneurial conditions. Cogent Business \& Management, 7(1), 1797261. https://doi.org/10.1080/2 3311975.2020.1797261 performance: empirical evidence from Iraq Stock Exchange (ISE). Academy of Accounting and Financial Studies Journal, 23(1), 1-11. Retrieved from https://search. proquest.com/openview/700f7a3e 8121ee734e523768c4781857/1?cbl $=29414 \&$ pq-origsite $=$ gscholar

4. Al-Azzawi, B. H. M. (2008). The Effect of the Relationship between
Strategic Intelligence and the Decisions of Service Operations in Strategic Success (Thesis). College of Management and Economics, University of Baghdad.

5. Al-Ghalbi, T. (2009). Management and Strategy of Medium and Small Business Organizations (1st ed.). Wael Publishing House.

6. Al-Hariri, R. (2012). Contemporary Management Trends (1st ed.). Dar Al-Fekr, Amman, Jordan. 
7. Al-Jubouri, M. A. (2019). The Management of Intangible Assets and their Role in Improving Financial Performance and Creating Value, Analytical Study of a Sample of Iraqi Private Banks. Transylvanian Review, 27(43), 12352-12364. Retrieved from https://www.researchgate.net/publication/335842243_The_Management_of_Intangible_Assets_and_ their_Role_in_Improving_Financial_Performance_and_Creating_Value_Analytical_Study_of_a_ Sample_of_Iraqi_Private_Banks

8. Al-Kamari, N. (2012). The Impact of Polarization Strategy and Building the Wise Capital on achieving Sustainable Tourism Development (Ph.D. Thesis). AlMustansiriya University.

9. Al-Qaryouti, M. (2005). Organization theory and organization. Dar Wael for Printing, Publishing and Distribution. Amman, Jordan. Retrieved from https://sites.google.com/site/drqarioti/published-refereed-research/ refereed

10. Al-Maghrabi. A. (2006). Administration, Academic Origins and Future Directions.: The Modern Library for Publishing and Distribution. Mansoura (Egypt). Retrieved from https:// library.iugaza.edu.ps/book_details. aspx?edition_no=76914

11. Al-Malkawi, A. (2015). Measuring the effectiveness of the Balanced Scorecard for managing strategic performance in Jordanian public institutions (a field study on the Social Security Corporation Irbid). Journal of managerial and Economical Sciences, 21(84), 60-85. Retrieved from http://www. dfaj.net/index.php?r=journals/ Journal\&i=290\&chk=1\#chech_link

12. Almaqtari, F. A., Al-Hattami, H. M., Al-Nuzaili, K. M., \& AlBukhrani, M. A. (2020). Corporate governance in India: A systematic review and synthesis for future research. Cogent Business \& Management, 7(1), 1803579. https://doi.org/10.1080/23311975. 2020.1803579

13. Almaqtari, F. A., Farhan, N. H. Yahya, A. T., \& Al-Homaidi, E. A.
(2020). Macro and socio-economic determinants of firms' financial performance: empirical evidence from Indian states. International Journal of Business Excellence, 21(4), 488-512. Retrieved from https:// ideas.repec.org/a/ids/ijbexc/v21y2020i4p488-512.html

14. Al-Mandalawi, A. K., (2015). Evaluation of Arabic language textbooks for the 6th grade in the light of the dimensions of the sustainable educational development. Master thesis, College of Education/Ibn Rushd, University of Baghdad. Retrieved from http://search.shamaa.org/ FullRecord?ID=113281

15. Al-Mughrabi, A. (2006). Scientific Assets Management and Future Trends. Al-Asria Library, Mansoura, Egypt. Retrieved from https://pmb univ-saida.dz/busegopac/index. php?lvl=author_see\&id $=193642$

16. Al-Zubaidi, H. (2012). Corporate Management and Social Responsibility for Companies A research submitted to the International Conference for the Development of Higher Education in Iraq for the period 27-29 November, Baghdad, Iraq.

17. Bontis, N., \& Fitz-enz, J. (2002). Intellectual Capital ROI: A causal map of human capital antecedents and consequents. Journal of Intellectual Capital, 3(3), 1-25. https://doi org/10.1108/14691930210435589

18. Carnall, C. (1999). Managing Change in Organizations (3rd ed.) London, Prentice-Hall Europe.

19. Central Statistical Organization (CSO). (2019). Annual Statistical Abstract 2018-2019. Retrieved from http://cosit.gov.iq/ar/2018-2019

20. Collins, D. (1996). Control and isolation in the management of empowerment. Empowerment in Organizations, 4(2), 29-39. https://doi. org/10.1108/09684899610118064

21. Desoky, A. M., \& Mousa, G. A.-H. (2020). The impact of intellectual capital on firm's financial performance: empirical evidence from Bahrain. Investment Management and Financial
Innovations, 17(4), 189-201. http://dx.doi.org/10.21511/ imfi.17(4).2020.18

22. Dess, G., \& Limpkin, G. T. (2005).

The Role of Entrepreneurial Orientation in simulating Effect Corporate Entrepreneurship. Academy of Management Perspectives, 19(1), 147156. https://doi.org/10.5465/ ame.2005.15841975

23. Elasrag, H. (2012). The developmental role of SMEs in the Arab countries. Munich Personal RePEc Archive. https://mpra. ub.uni-muenchen.de/40608/1/ MPRA_paper_40608.pdf

24. Ferrell, O. C., \& Hartline, M. D. (2005). Marketing Strategy. Thomson Corporation, USA. Retrieved from https://fac.ksu. edu.sa/sites/default/files/e_book marketing_strategy_ferrell_ hartline_5th_ed_2011.pdf

25. Jamil, C. M., \& Mohamed, R. (2011). Performance measurement system (PMS) in small medium enterprises (SMES): A practical modified framework. World Journal of Social Sciences, 1(3), 200-212. Retrieved from https://docplayer. net/13877328-Performance-measurement-system-pms-in-smallmedium-enterprises-smes-a-practical-modified-framework.html

26. Krol, F. (2007). Value Based Management in Small and Medium Enterprises. West Falsities Wilhelm's-Universidad Munster.

27. Mimar, S. (2004). Nurturing creativity. Knowledge Journal, 108(1), 102-126. Retrieved from http://www.almarefh.net/index. php?CUV=438\&Model $=\mathrm{M}$

28. Naushad, M. (2019). Intellectual capital and financial performance of sharia-compliant banks in Saudi Arabia. Banks and Bank Systems, 14(4), 1-9. https://doi.org/10.21511/ bbs.14(4).2019.01

29. O'Donnell, D., Tracey, M., Hendrickson, L., Bontis, N., Clearg, P., Kennedy, T., \& O’Regan, P. (2006). On the "essential condition" of intellectual capital labour. Journal of Capital, 7(1), 1-25. https://doi. org/10.1108/14691930610639804 
30. Project Management Institute (PMI). (2004). Knowledge Guide to Project Management (3rd ed.). Project Management Journal, Enterprise Corporation, USA.

31. Project Management Institute (PMI). (2008). A Guide to the Project Management Body of Knowledge (PMBOK Guide). Retrieved from https://www. pdfdrive.com/pmbok-guide-4theditionpdf-e22608028.html

32. Shubita, M. F. (2019).

Intellectual capital and market value: Evidence from Jordan. Investment Management and
Financial Innovations, 16(4), 37-45. https://doi.org/10.21511/ imfi.16(4).2019.04

33. Sidharta, I., Priadana, M. S., \& Affandi, A. (2019). Innovative behavior: The study of intellectual capital effect on creative fashion industry in Bandung, Indonesia Problems and Perspectives in Management, 17(4), 404415. https://doi.org/10.21511/ ppm.17(4).2019.33

34. Siwar, C., \& Hossain, T. (2009) An analysis of Islamic CSR concept and the opinions of Malaysian managers. Management of Environmental Quality,
20(3), 290-298. https://doi. org/10.1108/14777830910950685

35. Umanto, Wijaya, C., \& Atmoko, A. W. (2018). Intellectual capital performance of regional development banks in Indonesia. Banks and Bank Systems, 13(3), 36-47. https://doi.org/10.21511/ bbs.13(3).2018.04

36. Zeghal, D., \& Maaloul, A. (2010). Analyzing value added as an indicator of intellectual capital and its consequences on company performance. Journal of Intellectual Capital, 11(1), 39-60. https://doi. org/10.1108/14691931011013325 